\title{
Evaluasi pelaksanaan pengukuran tinggi badan oleh kader Posyandu di Wilayah Yogyakarta
}

\section{Evaluation of height measurements implemented by Posyandu Cadre In Yogyakarta}

\author{
Anindhita Syahbi Syagata ${ }^{1 *}$, Fayakun Nur Rohmah ${ }^{2}$, Khalisa Khairani ${ }^{3}$, \\ Siti Arifah ${ }^{4}$ \\ 1,2,3,4 Universitas ‘Aisyiyah Yogyakarta, Jalan Siliwangi No:63 Nogotirto Gamping Sleman, \\ Yogyakarta 55292, Indonesia \\ 12anindhita.s.syagata@unisayogya.ac.id*; ${ }^{2}$ fayakun.nurrohmah@unisayogya.ac.id; \\ ${ }^{3}$ khalisakhairani@unisayogya.ac.id, ${ }^{4}$ sitiarifah@unisayogya.ac.id \\ *corresponding author \\ Tanggal Submisi: . 29 Januari 2021, Tanggal Penerimaan: 20 April 2021
}

\begin{abstract}
Abstrak
Penelitian ini bertujuan untuk mengetahui praktek pengukuran tinggi badan di Posyandu wilayah Kecamatan Godean. Survei deskriptif observasional dengan desain cross-sectional digunakan dalam penelitian ini. Penelitian dilakukan di Posyandu Puskesmas Godean 1 dan 2 Kabupaten Sleman, pada AgustusSeptember 2019. Sebanyak 66 kader sebagai subjek diambil menggunakan strata random sampling. Teknik pengumpulan data menggunakan observasi langsung. Hasil penelitian menunjukkan lebih dari $70 \%$ kader mengukur tinggi badan anak yang tidak bersepatu, berdiri tegak menghadap ke depan, dan menarik tuas sampai ke ubun-ubun. Lebih dari 50\% kader mengukur tinggi badan dengan punggung, bokong, tumit menempel di dinding, dan membaca hasilnya dengan benar. Namun, hanya $27 \%$ yang memberikan koreksi hasil pengukuran anak berumur $<2$ tahun.
\end{abstract}

Kata kunci: kader posyandu; pengukuran tinggi badan; stunting

\begin{abstract}
This study aims to know practice on measuring height in Posyandu at Godean Sub-district area. Observational descriptive survey with cross-sectional designed used in this research. It was done in Posyandu at Godean 1 and 2 Primary Health Care, Sleman District, on August-September 2019. Sixtysix cadres as subjects collected using strata random sampling. The data collecting technique used direct observation. The result showed more than $70 \%$ cadre measured the height of children with no shoes, stand straight facing forward, and pull the lever up to the crown. More than 50\% cadre measured height with back, buttocks, heels against the wall, and read the results correctly. However, only $27 \%$ of them gave a correction when measuring the height of children under two.
\end{abstract}

Keywords: measurement height; posyandu cadre; stunting 


\section{PENDAHULUAN}

Salah satu target dalam World Health Assembly Resolution 65.6 tahun 2012 adalah menetapkan enam target gizi global untuk tahun 2025 salah satunya penurunan $40 \%$ kejadian stunting pada balita (World Health Organization, 2014). Angka prevalensi stunting dan malnutrisi Indonesia adalah salah satu yang tertinggi di negara-negara ASEAN, di mana satu dari tiga anak Indonesia berusia di bawah lima tahun mengalami stunting (Kementerian Perencanaan dan Pembangunan Nasional, 2019). Stunting adalah kondisi gagal tumbuh pada anak balita akibat dari kekurangan gizi kronis sehingga anak terlalu pendek untuk usianya. Kekurangan gizi terjadi sejak bayi dalam kandungan dan pada masa awal setelah bayi lahir, akan tetapi kondisi stunting baru terlihat setelah anak berusia 2 tahun. Indikator stunting adalah dengan melihat panjang badan $(\mathrm{PB} / \mathrm{U})$ atau tinggi badan (TB/U) menurut umurnya dibandingkan dengan standar baku WHO-MGRS (Multicentre Growth Reference Study) 2006. Sedangkan definisi stunting menurut Kementerian Kesehatan (Kemenkes) adalah anak balita dengan nilai z-scorenya kurang dari -2SD/standar deviasi (stunted) dan kurang dari - 3SD (severely stunted)(Tim Nasional Percepatan Penanggulangan Kemiskinan, 2017).

Riset Kesehatan Dasar (Riskesdas) 2018 menunjukkan prevalensi stunting sebesar 30,8\%, Soft Launching Hasil Survei Status Gizi Balita Indonesia (SSGBI) Oktober 2019 prevalensi stunting turun menjadi 27,67\% (Kementerian Kesehatan, 2020). Pemerintah dalam Rencana Pembangunan Jangka Menengah Nasional (RPJMN) 2020-2024 menekankan penurunan angka stunting ditargetkan menjadi 19\% pada 2024 (Kementerian Kesehatan, 2019). Penurunan angka stunting menjadi perhatian khusus pemerintah Indonesia. Pemerintah melalui melalui Perpres Nomor 42 Tahun 2013 menyatakan komitmennya dalam upaya percepatan perbaikan gizi dengan mencanangkan Gerakan Nasional (Gernas) Percepatan Perbaikan Gizi. Gerakan ini sebagai upaya bersama antara pemerintah dan masyarakat melalui penggalangan partisipasi dan kepedulian pemangku kepentingan secara terencana dan terkoordinasi untuk percepatan perbaikan gizi masyarakat dengan prioritas pada Seribu Hari Pertama Kehidupan (1000 HPK) (Kementerian Kesehatan Republik Indonesia, 2018).

Penyebab stunting diantaranya adalah kekurangan gizi kronis pada anak dalam jangka panjang, retardasi pertumbuhan intrauterine, kebutuhan protein tidak tercukupi sesuai proporsi total kalori, perubahan hormone dan infeksi pada awal kehidupan anak. Lebih lanjut asupan zat gizi makro dan mikro juga dapat dilihat sebagai faktor determinan (Syagata \& Mahfida, 2013; Teshome et al., 2010). Masalah stunting bukan hanya merupakan gangguan pertumbuhan fisik (bertubuh pendek/ kerdil), melainkan juga berpengaruh terhadap perkembangan otaknya, yang tentunya akan mempengaruhi kemampuan dan prestasi di sekolah, produktivitas, dan kreativitas di usia-usia produktif. Salah satu upaya pemerintah adalah dengan pemberian makanan tambahan pada balita dan ibu hamil untuk mencegah stunting (Kementerian Kesehatan Republik Indonesia, 2018). Hal tersebut untuk memberikan pemenuhan gizi yang adekuat pada ibu hamil dan balita. Penelitian menunjukkan bahwa pemberian makanan pada anak cenderung over-estimate sumber karbohidrat dan sayuran, serta under-estimate sumber protein hewani, protein nabati, dan buah (Mahfida, 2020). Selain itu, pemantauan pertumbuhan, peningkatan akses terhadap sanitasi dan air minum layak, 
perkembangan anak usia dini, dan menggalakkan pola asuh anak yang benar (Bappenas, 2017). E-konseling juga menjadi alternatif program di masa pandemi dimana kader tidak bisa intens bertemu dengan ibu bayi atau balita stunting (Sari et al., 2021). Berbagai upaya pemerintah tersebut dilakukan agar anak Indonesia bisa tumbuh menjadi generasi yang premium, berbudi pekerti luhur dan mampu berkompetisi di tingkat regional dan global. Dampak stunting bisa berlangsung sepanjang kehidupan. Stunting memengaruhi kapasitas belajar pada usia sekolah, nilai dan prestasi sekolah, upah kerja pada saat dewasa, risiko penyakit kronis seperti diabetes mellitus, morbiditas dan mortalitas, dan produktivitas ekonomi. Oleh sebab itu jika tidak ditangani dengan baik, persoalan stunting yang masif dapat menganggu produktivitas nasional dan mengancam masa depan generasi muda dan bangsa (Kementerian Kesehatan Republik Indonesia, 2019).

Program tersebut dibuat oleh pemerintah sudah sangat baik dan menjadi solusi yang konkrit untuk menjangkau seluruh lapisan masyarakat. Posyandu balita berperan besar dalam stimulasi, deteksi dini dan intervensi dini pada tumbuh kembang anak balita melalui penimbangan dan pengukuran tinggi badan anak (Fitriani \& Oktobriariani, 2017). Proses pengukuran tinggi badan/umur seharusnya menjadi agenda wajib dalam setiap kegiatan posyandu (Setyowati \& Astuti, 2015). Pada pelaksanannya, masih banyak kader yang melakukan pengukuran tinggi badan tidak sesuai dengan prosedur (Fuada, et al., 2014). Dari latar belakang tersebut, penelitian ini dilakukan untuk melakukan evaluasi pelaksanaan pengukuran TB anak usia 2-5 tahun yang dilakukan oleh kader.

Program tersebut dibuat oleh pemerintah sudah sangat baik dan menjadi solusi yang konkrit untuk menjangkau seluruh lapisan masyarakat. Posyandu balita berperan besar dalam stimulasi, deteksi dini dan intervensi dini pada tumbuh kembang anak balita melalui penimbangan dan pengukuran tinggi badan anak (Fitriani \& Oktobriariani, 2017). Proses pengukuran tinggi badan/umur seharusnya menjadi agenda wajib dalam setiap kegiatan posyandu (Setyowati \& Astuti, 2015). Pada pelaksanannya, masih banyak kader yang melakukan pengukuran tinggi badan tidak sesuai dengan prosedur (Fuada, et al., 2015). Dari latar belakang tersebut, penelitian ini dilakukan untuk melakukan evaluasi pelaksanaan pengukuran TB anak usia 2-5 tahun yang dilakukan oleh kader.

\section{METODE}

Penelitian ini menggunakan survey deskriptif observasional dengan pendekatan cross sectional dan dilakukan di Posyandu Wilayah Kerja Puskesmas Godean 1 dan 2 Kabupaten Sleman pada bulan Agustus-September 2019. Penelitian ini telah mendapat persetujuan Komisi Etik Penelitian Kesehatan dengan nomor 1161/KEP-UNISA/VI/2019. Pengukuran praktik dilakukan pada kader yang melakukan pengukuran tinggi badan (24-59 bulan). Dari 90 Posyandu, sebanyak 96 kader yang menandatangi inform consent masuk dalam penelitian ini yang kemudian terdapat Drop Out sehingga subjek berjumlah 74 kader Posyandu. Pengambilan subjek penelitian dengan metode strata random sampling. Sebanyak 66 kader Posyandu pada praktik pengukuran tinggi badan. Data diambil dengan cara observasi praktik pengukuran tinggi badan. Instrumen yang digunakan diambil dari buku pedoman Stimulasi, Deteksi, dan Intervensi Dini Tumbuh Kembang (SDIDTK) Kemenkes RI tahun 2016. 


\section{HASIL DAN PEMBAHASAN}

Berikut hasil pemeriksaan pengukuran tinggi badan pada balita saat posyandu wilayah Puskesmas Godean 1.

Tabel 1. Pelaksanaan Pengukuran Tinggi Badan oleh Kader Posyandu Wilayah Kecamatan Godean

\begin{tabular}{|c|c|c|c|c|c|c|c|}
\hline \multirow{2}{*}{ No } & \multirow{2}{*}{$\begin{array}{c}\text { Langkah Pengukuran Tinggi Badan } \\
\text { (24-72 bulan) }\end{array}$} & \multicolumn{2}{|c|}{ Benar } & \multicolumn{2}{|c|}{ Salah } & \multicolumn{2}{|c|}{ Jumlah } \\
\hline & & f & $\%$ & f & $\%$ & f & $\%$ \\
\hline 1 & Anak tidak memakai sandal atau sepatu & 58 & 87,88 & 8 & 12,12 & 66 & 100 \\
\hline 2 & Berdiri tegak menghadap ke depan & 57 & 86,36 & 9 & 13,64 & 66 & 100 \\
\hline 3 & $\begin{array}{l}\text { Punggung, pantat, dan tumit menempel } \\
\text { pada tiang pengukur }\end{array}$ & 39 & 59,09 & 27 & 40,91 & 66 & 100 \\
\hline 4 & $\begin{array}{l}\text { Turunkan batas atas pengukur sampai } \\
\text { menempel di ubun-ubun }\end{array}$ & 49 & 74,24 & 17 & 25,76 & 66 & 100 \\
\hline 5 & $\begin{array}{l}\text { Baca angka pada batas tersebut dengan } \\
\text { mata sejajar }\end{array}$ & 36 & 54,55 & 30 & 45,45 & 66 & 100 \\
\hline 6 & $\begin{array}{l}\text { Jika anak umur di atas } 24 \text { bulan diukur } \\
\text { terlentang, maka hasil pengukurannya } \\
\text { dikoreksi dengan mengurangkan } 0,7 \\
\mathrm{~cm} \text { sedangkan pada anak kurang dari } \\
24 \text { bulan yang diukur berdiri maka } \\
\text { hasil pengukurannya dikoreksi dengan } \\
\text { menambahkan } 0,7 \mathrm{~cm}\end{array}$ & 18 & 27,27 & 48 & 72,73 & 66 & 100 \\
\hline
\end{tabular}

Pengukuran tinggi badan di Posyandu dalam penelitian ini menggunakan microtoise. Dari tabel 1, 87.9\% kader sudah bisa melakukan langkah pertama, yaitu anak tidak menggunakan alas kaki, baik sendal maupun sepatu. Ini sesuai dengan prosedur yang melepas alas kaki dan aksesori kepala (jepit rambut, dasi, dan topi) (Bachtiar \& Madjid, 2015; Fuada et al., 2014). Posisikan anak menghadap ke depan dengan menempelkan pengukur atau dinding dengan kaki telanjang berdekatan, kaki lurus, lengan di samping, dan bahu rileks (Centre for Population Health New South Wales, 2017; Fuada et al., 2014). Selanjutnya, kader hendaknya membuat pakaian yang seminim mungkin agar posturnya dapat terlihat jelas (Bachtiar \& Madjid, 2015). Lebih dari 85\% kader sudah melakukan langkah kedua, berdiri tegak menghadap ke depan.

Fuada (2015) dalam penelitiannya menunjukkan hanya 35\% kader yang dapat memposisikan anak (kepala, punggung, pantat, dan tumit) dengan tepat pada dinding atau tiang pengukur (Fuada et al., 2014). Sejalan dengan penelitian ini, 59\% kader telah melakukan langkahnya dengan benar. Mereka harus memastikan lutut lurus, tumit berada di lantai, dan kepala, bahu, pantat, dan tumit bersentuhan dengan stadiometer (tiang pengukur) atau dinding. Pastikan lengan berada di sisi mereka, bahu relaks, dan anak berdiri tegak di tengah-tengah tongkat pengukur (Centers for Disease Control and Prevention (CDC), 2007; Centre for Population Health New South Wales, 2017). Dalam kondisi tertentu seperti kyphosis (kelainan tulang belakang yang membuat punggung bagian atas tampak membulat), keempat titik (kepala, bahu, pantat, dan tumit) mungkin tidak dapat bersentuhan dengan tiang atau dinding pengukur (Centers for Disease 
Control and Prevention (CDC), 2007). Dalam penelitian ini, kesalahan yang paling sering ditemukan pada tahap ini adalah memposisikan tumit pada batang pengukur atau dinding.

Langkah keempat adalah menurunkan bagian atas pengukur hingga menempel di ubun-ubun. Sebanyak 74\% kader sudah dilakukan dengan benar. Pada tahap ini, penggaris perlahan ditarik ke bawah dengan tekanan yang cukup untuk menekan rambut. Anak dimimta untuk menarik napas dan menahan selama beberapa saat untuk tahap ini. Tindakan menarik napas dalam membantu meluruskan tulang belakang agar pengukurannya konsisten. Jika dalam beberapa kondisi misalnya gaya rambut tidak bisa dikondisikan, maka anak tetap diposisikan sesuai prosedur. Kesalahan pada tahap ini adalah sebagian kader kurang memperhatikan batas ukur tepat di tengah kepala anak karena beberapa faktor diantaranya anak rewel.

Sebesar 54\% kader dalam penelitian membaca hasil dengan benar yaitu dengan memposisikan mata sejajar pada alat pengukur. Pada pengukuran panjang badan dengan microtoise, kader membaca angka pada jendela baca dan mata pembaca (kader) harus sejajar dengan garis merah. Angka yang dibaca adalah yang berada pada garis merah dari angka kecil ke arah angka besar (Sutiari, 2017). Hasil ini serupa dengan penelitian sebelumnya hanya sekitar 59\% kader yang membaca hasil dengan benar. Kesalahan yang sering terjadi saat pembacaan hasil adalah posisi pembaca tidak sejajar dengan jendela baca pada microtoise dan membaca hasil dari atas, atau samping (Fuada et al., 2014).

Langkah terakhir adalah melakukakan koreksi apabila pengukuran panjang badan tidak sesuai dengan umur. Mayoritas kader tidak melakukan koreksi terhadap hasil pengukuran, hanya 27\% kader yang melakukan koreksi terhadap hasil. Hasil observasi menunjukkan bahwa kader melakukan pengukuran posisi berdiri atau tinggi badan untuk anak $<24$ bulan tanpa melakukan koreksi (ditambah 0,7 cm). Dalam kondisi tertentu pengukuran tinggi badan pada anak > 24 bulan mungkin saja dilakukan berbaring seperti dalam kondisi ketika seorang anak sakit dan terlalu lemah untuk berdiri karena kendala waktu / peralatan, dan hanya mungkin mengukur semua anak yang berbaring. MGRS melakukan pengukuran panjang dan tinggi badan. Perbedaan rata-rata antara keduanya pengukuran pada kelompok 1625 ini adalah $0,73 \mathrm{~cm}$. Agar sesuai dengan model tunggal untuk seluruh rentang usia, Oleh karena itu $0,7 \mathrm{~cm}$ ditambahkan ke nilai tinggi penampang sebelum menggabungkannya dengan data panjang sampel longitudinal (Hospital Care for Children, n.d.; World Health Organization (WHO), 2006). Sehingga jika anak umur di atas 24 bulan diukur terlentang, maka hasil pengukurannya dikoreksi dengan mengurangkan $0,7 \mathrm{~cm}$ sedangkan pada anak kurang dari 24 bulan yang diukur berdiri maka hasil pengukurannya dikoreksi dengan menambahkan $0,7 \mathrm{~cm}$. Panjang Badan dalam keadaan berbaring (Recumbent length) berada pada ukuran rata-rata $0.7 \mathrm{~cm}$ lebih panjang dari tinggi. Jika mengukur panjang anak lebih dari 2 tahun dalam keadaan berbaring terlentang maka hasil pengukuran dikurangi 0,7 sentimeter dari hasil pengukuran panjang untuk mengubahnya menjadi tinggi, karena pengukuran panjang biasanya lebih besar dari pengukuran tinggi (Bachtiar \& Madjid, 2015; World Health Organization (WHO), 2006, 2009) (Widardo et al., 2018). Berikut adalah gambar Teknik pengukuran tinggi badan yang tepat: 

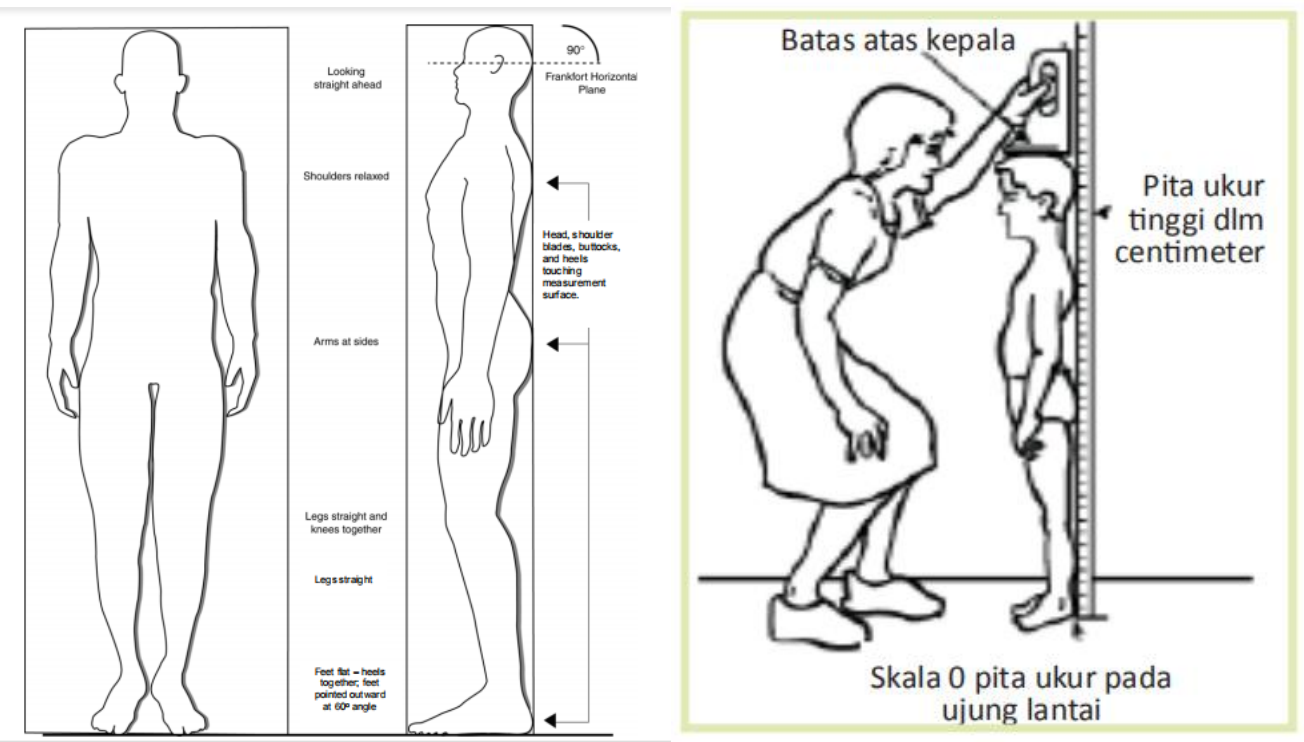

Gambar 1. Pengukuran Panjang Badan

(Sumber: Kemenkes, 2016)

Kesalahan yang terjadi pada saat pengukuran berpengaruh terhadap presisi, akurasi, dan validitas hasil pengukuran. Beberapa kesalahan biasanya berhubungan dengan ketrampilan kader yang tidak cukup, kesalahan alat dan kesulitan saat melakukan pengukuran (Susilowati, 2008). Ketrampilan kader didasari oleh pengetahuan kader tentang pengukuran tinggi badan. Hardiyanti dkk (2018) dalam penelitiannya menunjukkan bahwa pengetahuan kader berkaitan dengan akurasi pengukuran yang dilakukan, kader dengan pengetahuan yang baik memiliki tingkat presisi yang baik sebesar $92,1 \%$ dan kader yang memiliki pengetahuan yang kurang memiliki tingkat presisi yang baik sebesar 35\% (Hardiyanti et al., 2018). Kesalahan yang sering terjadi karena faktor anak adalah anak rewel dan menangis, hal ini menyebabkan kader tidak bisa memosisikan anak dengan tepat dan terburu-buru untuk membaca hasilnya (Metty \& Inayah, 2018).

\section{SIMPULAN}

Sebagian besar kader sudah melaksanakan prosedur yang baik pada pemosisian anak dalam pengukuran tinggi badan. Langkah koreksi pada hasil pengukuran memerlukan perhatian karena sebagian besar kader tidak melaksanakan. Hal ini akan berdampak pada data stunting yang dikumpulkan dari kader posyandu untuk Puskemas. Data dari Puskesmas yang diinput dalam aplikasi pencatatan dan pelaporan gizi berbasis masyarakat (e-ppgbm) oleh kader akan digunakan dalam skala nasional, yang artinya peran kader dalam setiap langkah pengukuran menjadi krusial.

\section{SARAN}

Perlunya penyegaran kembali tentang teknik pengukuran panjang badan pada kader secara berkala dan monitoring dari Puskesmas terhadap pelaksanaan posyandu 


\section{DAFTAR PUSTAKA}

Bachtiar, R. R., \& Madjid, B. (2015). Buku Panduan Pendidikan Keterampilan Klinik 1. In Fakultas Kedokteran Universitas Hasanuddin.

Bappenas. (2017). Peta Jalan SDGs Indonesia Menuju 2030.

Centers for Disease Control and Prevention (CDC). (2007). Anthropometry procedures manual. National Health and Nutrition Examinatory Survey (NHANES), January, 3-1-3-26.

Centre for Population Health New South Wales. (2017). Growth Assessment in Children and Weight Status Assessment in Adults. In Growth Assessment in Children and Weight Status Assessment in Adults.

Fitriani, I. S., \& Oktobriariani, R. R. (2017). Stimulasi, Deteksi dan Intervensi Dini Orang Tua terhadap Pencegahan Penyimpangan Pertumbuhan dan Perkembangan Anak Balita. Indonesian Journal for Health Sciences, 1 (1), 1. https://doi.org/10.24269/ijhs.v1i1.383

Fuada, N., Salimar, S., \& Irawati, A. (2014). Kemampuan Kader Posyandu Dalam Melakukan Pengukuran Panjang/Tinggi Badan Balita. Jurnal Ekologi Kesehatan, $13(3 \quad$ Sep), 229-239-239. https://doi.org/10.22435/jek.v13i3Sep.5118.229-239

Hardiyanti, R., Jus'at, I., \& Angkasa, D. (2018). A relationship from long working to cadre, knowledge, education, training with precision and accuracy of weighing result by cadre at Integrated Health Post. Action: Aceh Nutrition Journal, 3(1), 74. https://doi.org/10.30867/action.v3i1.

Hospital Care for Children. (n.d.). Menghitung Berat Badan anak Menurut Panjang/Tinggi Badan.

Kementerian Kesehatan. (2019). Kementerian kesehatan fokus pada pencegahan stunting. In 2019 (Issue November 2019, pp. 1-9).

Kementerian Kesehatan. (2020). Sekretariat Kabinet Republik Indonesia _ Menko PMK_ Target Angka "Stunting" di Bawah 680 Ribu Per Tahun- Sekretariat Kabinet Republik Indonesia.

Kementerian Kesehatan Republik Indonesia. (2018). Warta Kesmas - Cegah Stunting Itu Penting. Warta Kesmas, 02, 1-27.

Kementerian Kesehatan Republik Indonesia. (2019). Perangi Stunting dengan Jaga Periode Usia Emas Indonesia.

Kementerian Perencanaan dan Pembangunan Nasional. (2019). Peta Jalan SDGs Indonesia Menuju 2030. 
Mahfida, S. L. (2020). Usia, Status Gizi, dan Berat Badan Anak Sebagai Faktor Determinan dalam Estimasi Porsi Makan oleh Ibu. JHeS (Journal of Health Studies), 4(2), 26-32. https://doi.org/10.31101/jhes.1141

Metty, \& Inayah. (2018). Pelatihan Pengukuran Antropometri Dan Sosialisasi Pedoman Gizi Seimbang Pada Kader Posyandu Johar XII Rusun Jogoyudan, Jetis, Kota Yogyakarta. Jurnal Pengabdian Dharma Bakti, 1(1), $39-45$.

Sari, I. Y., Prawesti, I., \& Febrianti, S. (2021). E-counseling Nutrisi Berbasis Media Sosial sebagai Upaya Menurunkan Angka Stunting. Jurnal Kebidanan Dan Keperawatan Aisyiyah, 16(2), 156-166. https://doi.org/10.31101/jkk.1793

Setyowati, M., \& Astuti, R. (2015). Mapping the Nutritional Status of Children in Support of. Jurnal Kesehatan Masyarakat, 10(2), 110-121.

Susilowati. (2008). Pengukuran Status Gizi dengan Antropometri Gizi. 1-76.

Sutiari, N. K. (2017). Petunjuk praktikum Penilaian Status Gizianthropometry dan Dietary Assesssment. Program Studi Kesehatan Masyarakat fakultas Kedokteran Universitas Udayana Denpasar.

Syagata, A. S., \& Mahfida, S. L. (2013). Tinjauan Pustaka Suplementasi Vitamin A Dosis Tinggi Di Indonesia. Jurnal Berkala Ilmiah Mahasiswa Gizi Indonesia, 2(1), 41-46.

Teshome, B., Kogi-Makau, W., Getahun, Z., \& Taye, G. (2010). Magnitude and determinants of stunting in children underfive years of age in food surplus region of Ethiopia: The case of West Gojam Zone. Ethiopian Journal of Health Development, 23(2). https://doi.org/10.4314/ejhd.v23i2.53223

Tim Nasional Percepatan Penanggulangan Kemiskinan. (2017). 100 Kabupaten/Kota Prioritas untuk Intervensi Anak Kerdil (Stunting). 1-27.

Widardo, Wiboworin, B., Wiyono, N., \& Dkk. (2018). Buku Manual Keterampilan Klinik Topik Antropometri. Kementerian Riset, Teknologi, Dan Pendidikan Tinggi Universitas Sebelas Maret Fakultas Kedokteran, 36, $15-16$.

World Health Organization. (2014). WHA Global Nutrition Targets 2025: Stunting Policy Brief. Economics and Human Biology. https://doi.org/10.1016/j.ehb.2005.05.005

World Health Organization (WHO). (2006). WHO Child Growth Standards. In Developmental Medicine \& Child Neurology (Vol. 51, Issue 12). https://doi.org/10.1111/j.1469-8749.2009.03503.x

World Health Organization (WHO). (2009). WHO AnthroPlus for Personal 


\section{Computers Manual.}

Anindhita Syahbi Syagata et.al (Evaluasi pelaksanaan pengukuran tinggi badan oleh kader....)

Copyright (C 2021, Jurnal Kebidanan dan Keperawatan Aisyiyah ISSN 1858-0610 (print) | ISSN 2477-8184 (Online) 